\title{
ANALISIS BERORIENTASI OBJEK DALAM PENENTUAN TINGKAT KREATIVITAS SISWA DENGAN METODE FUZZY MAMDANI
}

\author{
Indra Kurniawan ${ }^{1}$, Rahman Abdillah ${ }^{2}$ \\ Program Studi Informatika, Universitas Indraprasta PGRI ${ }^{1,2}$ \\ Email: inkur.master@gmail.com
}

\begin{abstract}
Abstrak
Kemampuan pemecahan masalah mempersyaratkan kemampuan berpikir kreatif dalam mengeksplorasi berbagai alternatif cara atau solusi. kemampuan berpikir seseorang memiliki tingkatan sesuai karya yang dihasilkan oleh orang itu. Oleh karena itu, dilakukan analisis penentuan tingkat kreativitas siswa dengan metode fuzzy mamdani. Tujuan dari penelitian ini adalah untuk mengetahui proses penentuan tingkatan kreativitas siswa dengan metode fuzzy mamdani. Metode penelitian ini menggunakan survei dengan jenis penelitian kualitataif dimana dalam penggumpulan data dilakukan dengan teknik observasi, wawancara dan kepustakaan.
\end{abstract}

Kata Kunci : Analisis Berorientasi Objek, Kreativitas Siswa, Fuzzy Mamdani

\section{Abstract}

Problem-solving skill requires the ability to think creatively in exploring various alternatives or solutions. Someone's ability to think has different levels depending on works he produces. Therefore, it is necessary to carry out an analysis of the determination of student's creativity level by employing a fuzzy mamdani method. The aim of this research is to know the process of determining the student's creativity level by using a fuzzy mamdani method. The research applies a survey method with a qualitative research model in which the data are collected by observation, interview and literature review techniques.

Keywords: Object-Oriented Analisis, Student's Creativity, Fuzzy Mamdani

\section{PENDAHULUAN}

Kreativitas dan pemecahan masalah sangat berkaitan erat. Kemampuan pemecahan masalah mempersyaratkan kemampuan berpikir kreatif dalam mengeksplorasi berbagai alternatif cara atau solusi. Kreativitas merupakan salah satu cara yang dianjurkan untuk dapat mengembangkan kemampuan dirinya. Hal ini sesuai dengan penelitian yang menyatakan "creative thinking is related to all of the perspectives, and a strong belief in any particular perspective may result in a tendency" [1].

Kemampuan kreativitas siswa akan dapat berkembang dengan baik jika mampu mengeluarkan atau mengaktualisasikan diri sesuai dengan daya kreasinya. Sehingga siswa akan mendapatkan sesuatu cara yang baru dalam memecahkan sebuah masalah. Hal ini sesuai penelitian yang menyatakan bahwa kreatif akan dapat mendorong siswa untuk menggerakan pada konsep atau cara yang berbeda dalam menyelesaikan permasalahan [2].

Unsur kreatif diperlukan untuk menyelesaikan masalah karena semakin kreatif maka akan semakin banyak alternatif penyelesaiannya. Hal ini sesuai dengan penelitian yang menyatakan bahwa "creativity can a rise from a combination of conscious thinking and the unconscious thinking that occurs during a non-working period of incubation" [3]. Untuk dapat berpikir kreatif ada proses yang harus dilakukan. Proses berpikir kreatif timbul dari pribadi seseorang, sehingga dalam proses memecahkan suatu masalah setiap individu mempunyai cara yang berbeda.

Siswa yang sudah mampu melakukan proses berpikir kreatif maka akan mampu melihat persoalan dari banyak perspektif dan dapat menghasilkan lebih banyak 
alternatif untuk memecahkan suatu masalah. Kreativitas pemecahan masalah mempunyai tiga komponen, yaitu: kefasihan (fluency), fleksibilitas (flexibility), dan kebaruan (novelty). Kemampuan berpikir seseorang memiliki tingkatan sesuai karya yang dihasilkan oleh orang itu [4]. Oleh karena itu, dilakukan analisis penentuan tingkat kreativitas siswa dengan metode fuzzy mamdani.

Logika fuzzy adalah suatu cara yang tepat untuk memetakan suatu ruang input ke dalam suatu ruang output. Logika fuzzy adalah perluasan dari banyaknya nilai logika di dalam arti dari pembentukan fuzzy set dan fuzzy relation sebagai tool menjadi sistem yang banyak nilai logika [5]. Sistem Inferensi Fuzzy (Fuzzy Inference System / FIS) disebut juga fuzzy inference engine adalah sistem yang dapat melakukan penalaran dengan prinsip serupa seperti manusia melakukan penalaran dengan nalurinya.

Metode Mamdani sering juga dikenal dengan metode Max-Min pada metode Mamdani, terdapat 4 tahap untuk mendapatkan output, yaitu:

1. Fuzzyfication, pada tahap pertama ini, nilai input yang berupa nilai crisp akan dikonversikan menjadi nilai fuzzy, sehingga dapat dikelompokkan pada himpunan fuzzy tertentu. Tahap ini juga menentukan himpunan fuzzy untuk output.

2. Rule Evaluation, langkah kedua adalah mengambil nilai input yang dikonversi menjadi nilai fuzzy dan diaplikasikan ke dalam antecedents pada aturan fuzzy lalu diimplikasikan. Fungsi implikasi yang digunakan adalah Min.

3. Rule Aggregation, adalah proses dari penggabungan nilai keluaran dari semua aturan. Pada tahap ini, digunakan metode Max, dimana solusi himpunan fuzzy diperoleh dengan cara mengambil nilai maksimum aturan, yang kemudian digunakan untuk memodifikasi daerah fuzzy.

4. Defuzzification, langkah terakhir dari proses inferensi fuzzy adalah untuk mengkonversi nilai fuzzy hasil dari aggregasi aturan ke dalam sebuah bilangan crisp.

\section{METODE}

Jenis penelitian ini adalah penelitian kualiatif deskriptif dengan metode penelitian. Pengumpulan data dilakukan dengan multistage sampling yaitu mencari sampel dari penelitian dengan teknik pengumpulan data secara bertahap. Penentuan subjek penelitian dalam penelitian kualitatif ini menggunakan model criterion-based selection yang didasarkan pada asusmsi bahwa subjek tersebut sebagai aktor dalam tema penelitian yang diajukan. Selain itu dalam penentuan informan, dapat menggunakan model snow ball sampling untuk memperluas subjek penelitian.

Setelah rangkaian data terkumpul, selanjutnya dilakukan analisis data dengan prosedur dan teknis pengolahan berikut:

1. Melakukan pemilahan dan penyusunan klasifikasi data.

2. Melakukan penyunting data dan pemberian kode data untuk membangun kinerja analisis data.

3. Melakukan konfirmasi data yang memerlukan verifikasi data dan pendalaman data.

4. Melakukan analisis data sesuai dengan konstruksi pembahasan hasil penelitian.

\section{HASIL DAN PEMBAHASAN}

Berdasarkan data yang berhasil dikumpulkan oleh peneliti, maka diperoleh data siswa sebagai berikut: 
Tabel 1. Hasil Analisis Data Kelima Siswa

\begin{tabular}{|c|c|c|c|}
\hline \multirow{2}{*}{ Siswa } & \multicolumn{3}{|c|}{ Komponen Tingkatan Kreativitas } \\
\hline & Kefasihan & Fleksibilitas & Kebaharuan \\
\hline S-1 & $\begin{array}{l}\text { Siswa mengerjakan } \\
\text { dengan cara eliminasi } \\
\text { dengan jelas dan benar }\end{array}$ & $\begin{array}{l}\text { Siswa mengerjakan } \\
\text { dengan cara subtitusi } \\
\text { dengan jelas dan benar }\end{array}$ & $\begin{array}{l}\text { Siswa mengerjakan } \\
\text { dengan cara baru yaitu } \\
\text { diagram ven dengan jelas } \\
\text { dan benar }\end{array}$ \\
\hline $\mathrm{S}-2$ & $\begin{array}{l}\text { Siswa mengerjakan } \\
\text { dengan cara eliminasi } \\
\text { dengan jelas dan benar }\end{array}$ & - & $\begin{array}{l}\text { Siswa mengerjakan } \\
\text { dengan cara baru yaitu } \\
\text { dengan logika/rumus } \\
\text { sederhana yang } \\
\text { dibuatnya sendiri dengan } \\
\text { jelas dan benar }\end{array}$ \\
\hline$S-3$ & $\begin{array}{l}\text { Siswa mengerjakan } \\
\text { dengan cara eliminasi } \\
\text { dengan jelas dan benar }\end{array}$ & $\begin{array}{l}\text { Siswa mengerjakan } \\
\text { dengan cara subtitusi } \\
\text { dengan jelas dan benar }\end{array}$ & $\begin{array}{l}\text { Siswa mencoba } \\
\text { mengerjakan dengan cara } \\
\text { baru tetapi tidak yakin } \\
\text { walaupun jawabnya } \\
\text { benar }\end{array}$ \\
\hline S-4 & $\begin{array}{l}\text { Siswa mengerjakan } \\
\text { dengan cara eliminasi } \\
\text { dengan jelas dan benar }\end{array}$ & $\begin{array}{l}\text { Siswa mengerjakan } \\
\text { dengan cara subtitusi } \\
\text { dengan jelas dan benar }\end{array}$ & - \\
\hline S-5 & $\begin{array}{l}\text { Siswa mengerjakan } \\
\text { dengan cara eliminasi } \\
\text { dengan jelas dan benar }\end{array}$ & - & - \\
\hline
\end{tabular}

Masing-masing komponen parameter penghitungan tingkat kreativitas siswa jika dijumlah terdapat nilai maks $=1$ yang berasal dari (Kefasihan + Fleksibilitas + Kebaharuan). Berdasarkan hasil data yang diterima penulis, maka akan didapat transformasi yang dapat dilihat seperti pada Tabel 2.

Tabel 2. Transformasi Data Qualitative Tingkat Kreativitas Siswa Komponen Tingkatan Kreativitas

\begin{tabular}{cccc} 
Siswa & $\begin{array}{c}\text { Kefasihan } \\
(0.3)\end{array}$ & $\begin{array}{c}\text { Fleksibilitas } \\
(0.3)\end{array}$ & $\begin{array}{c}\text { Kebaharuan } \\
(0.4)\end{array}$ \\
\hline S-1 & 0.3 & 0.3 & 0.4 \\
S-2 & 0.3 & 0 & 0.4 \\
S-3 & 0.3 & 0.3 & 0,05 \\
S-4 & 0.3 & 0.3 & 0 \\
S-5 & 0.3 & 0 & 0 \\
\hline
\end{tabular}

Selanjutnya, dari data tersebut jika masingmasing parameter dihitung untuk mendapat hasil tingkat kreativitas siswa adalah sebagai berikut:
Tabel 3. Transformasi Nilai Tingkat Kreativitas Masing-Masing Siswa

\begin{tabular}{ccccc}
\hline \multirow{4}{*}{ Komponen Tingkat Kreativitas } \\
SISWA & $\begin{array}{c}\text { Kefa- } \\
\text { sihan } \\
{[0.3]}\end{array}$ & $\begin{array}{c}\text { Flek- } \\
\text { sibilitas } \\
{[0.3]}\end{array}$ & $\begin{array}{c}\text { Keba- } \\
\text { Haruan } \\
{[0.4]}\end{array}$ & $\begin{array}{c}\text { Tingkat } \\
\text { Kreativitas } \\
{[1.0]}\end{array}$ \\
\hline S-1 & 0.3 & 0.3 & 0.4 & 1.0 \\
S-2 & 0.3 & 0 & 0.4 & 0.7 \\
S-3 & 0.3 & 0.3 & 0.05 & 0.65 \\
S-4 & 0.3 & 0.3 & 0 & 0.6 \\
S-5 & 0.3 & 0 & 0 & 0.3 \\
\hline
\end{tabular}

Proses Pengembangan Fuzzy Inference System (Mamdani):

Spesifikasi masalah kemudian definisikan linguistic variables, untuk mengukur tingkat kreativitas ada 3 parameter yang digunakan yaitu tingkat kefasihan, tingkat fleksibilitas dan tingkat kebaruan. Adapun pengembangan dari hasil referensi qualitative method tingkat kreativitas siswa dapat dilihat melalui Tabel 4, Tabel 5, Tabel 6 dan Tabel 7 sebagaimana berikut ini: 
Tabel 4. Spesifikasi Masalah dan Definisi dalam Linguistic Variables Kefasihan

\begin{tabular}{ccc}
\hline \multicolumn{3}{c}{ Linguistic Variable: Kefasihan } \\
$\begin{array}{c}\text { Linguistic } \\
\text { Variable }\end{array}$ & Notation & $\begin{array}{c}\text { Numerical Range } \\
\text { (normalized) }\end{array}$ \\
\hline Sangat Fasih & SFS & {$[0.75,1]$} \\
Fasih & FS & {$[0.5,0.85]$} \\
Kurang Fasih & KFS & {$[0,0.65]$} \\
\hline
\end{tabular}

Tabel 5. Spesifikasi Masalah dan Definisi Dalam Linguistic Variables Fleksibilitas

\begin{tabular}{|c|c|c|}
\hline \multicolumn{3}{|c|}{ Linguistic Variable: Fleksibilitas } \\
\hline $\begin{array}{l}\text { Linguistic } \\
\text { Variable }\end{array}$ & Notation & $\begin{array}{l}\text { Numerical Range } \\
\text { (normalized) }\end{array}$ \\
\hline $\begin{array}{c}\text { Sangat } \\
\text { Fleksibel }\end{array}$ & SFL & {$[0.7,1]$} \\
\hline Fleksibel & FL & {$[0.4,0.75]$} \\
\hline $\begin{array}{l}\text { Kurang } \\
\text { Fleksibel }\end{array}$ & KFL & {$[0,0.55]$} \\
\hline
\end{tabular}

Tabel 6. Spesifikasi Masalah dan Definisi dalam Linguistic Variables Kebaharuan

\begin{tabular}{|c|c|c|}
\hline \multicolumn{3}{|c|}{ Linguistic Variable: Kebaharuan } \\
\hline $\begin{array}{c}\text { Linguistic } \\
\text { Variable }\end{array}$ & Notation & $\begin{array}{c}\text { Numerical Range } \\
\text { (normalized) }\end{array}$ \\
\hline $\begin{array}{l}\text { Metode } \\
\text { Terbaru }\end{array}$ & MB & {$[0.8,1]$} \\
\hline $\begin{array}{l}\text { Metode } \\
\text { Kombinasi }\end{array}$ & MK & {$[0.5,0.85]$} \\
\hline $\begin{array}{l}\text { Metode } \\
\text { Lama }\end{array}$ & ML & {$[0,0.6]$} \\
\hline
\end{tabular}

Tabel 7. Spesifikasi Masalah dan Definisi dalam Linguistic Variables Tingkat Kreativitas

\begin{tabular}{ccc}
\hline \multicolumn{3}{c}{ Linguistic Variable: Tingkat Kreativitas } \\
$\begin{array}{c}\text { Linguistic } \\
\text { Variable }\end{array}$ & Notation & $\begin{array}{c}\text { Numerical Range } \\
\text { (normalized) }\end{array}$ \\
\hline Sangat Kreatif & SK & {$[0.7,1]$} \\
Kreatif & KR & {$[0.6,0.8]$} \\
Cukup Kreatif & CK & {$[0.4,0.65]$} \\
Kurang Kreatif & KK & {$[0,0.5]$} \\
\hline
\end{tabular}

Menentukan himpunan fuzzy dengan Matlab FIS Editor

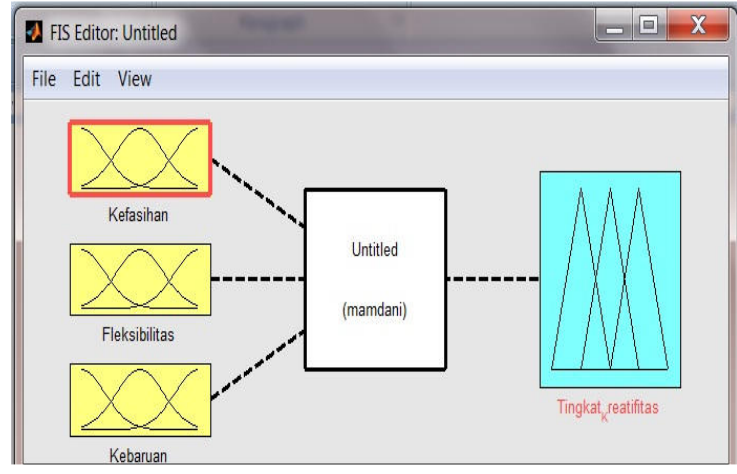

Gambar 1. Inisiasi Awal Tingkat Kreativitas dalam Matlab FIS Editor

Setelah menentukan spesifikasi masalah dan menentukan rentang penilaian dalam linguistic variables, selanjutnya dapat diproses penghitungannya dengan menggunakan Matlab. Langkahnya adalah dengan memasukkan nilai masing-masing indikator. Adapun masing-masing indikator tingkat kreativitas adalah sebagai berikut :

Himpunan fuzzy dari Kefasihan

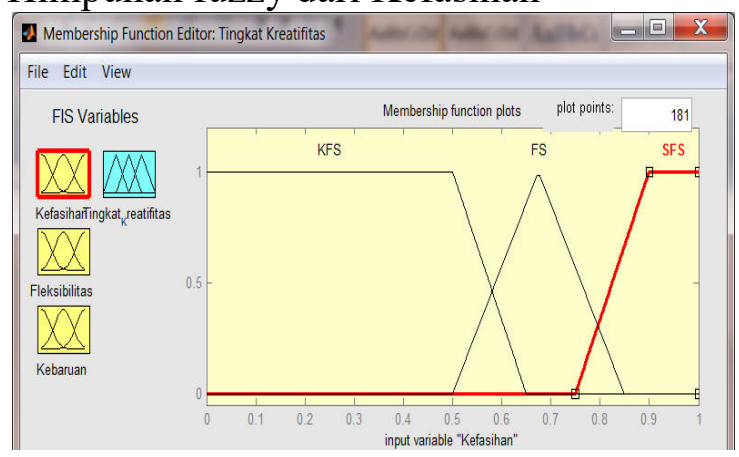

Gambar 2. Membership Function Tingkat Kefasihan

Himpunan Fuzzy dari Fleksibilitas

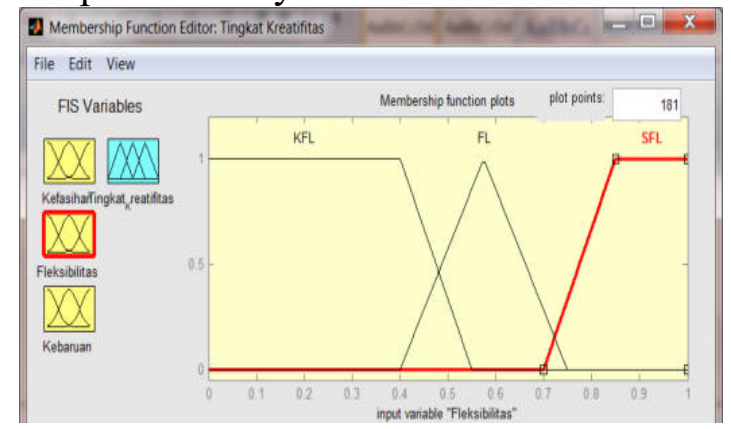

Gambar 3. Membership Function Tingkat Fleksibiltas 
Himpunan Fuzzy dari Kebaharuan

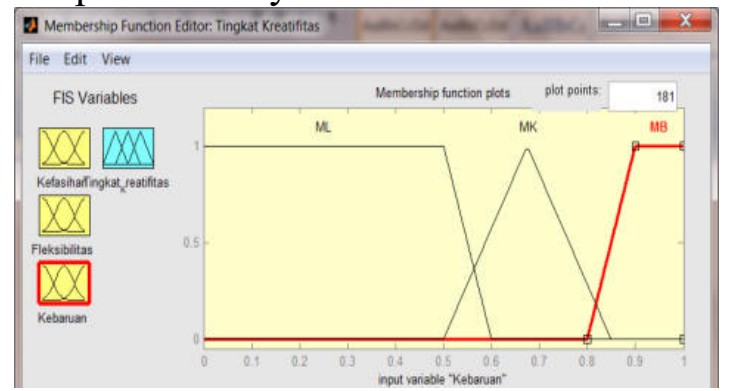

Gambar 5. Membership Function Tingkat Kebaruan

Himpunan Fuzzy dari Tingkat Kreativitas

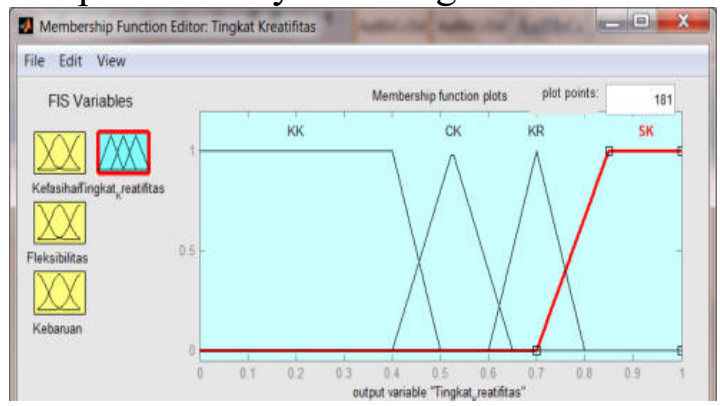

Gambar 6. Output Membership Function Tingkat Kreativitas

\section{Membuat Aturan Fuzzy}

Setelah memasukkan nilai pada masingmasing indikator tingkat kreativitas, selanjutnya membuat aturan fuzzy. Adapun aturan yang dibuat penulis kedalam fuzzy rule editor adalah sebagai berikut :

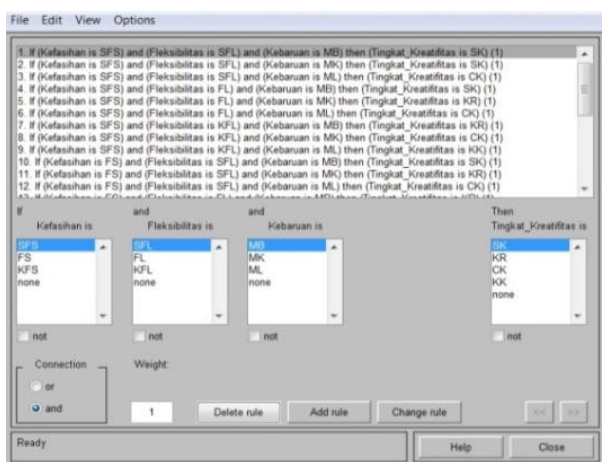

Gambar75. Fuzzy Rule Editor

Aturan Fuzzy tingkat Kreativitas adalah sebagai berikut :

1. If (Kefasihan is SFS) and (Fleksibilitas is SFL) and (Kebaruan is MB) then (Tingkat_Kreativitas is SK)
2. If (Kefasihan is SFS) and (Fleksibilitas is $\mathrm{SFL}$ ) and (Kebaruan is MK) then (Tingkat_Kreativitas is SK)

3. If (Kefasihan is SFS) and (Fleksibilitas is SFL) and (Kebaruan is ML) then (Tingkat_Kreativitas is CK)

4. If (Kefasihan is SFS) and (Fleksibilitas is FL) and (Kebaruan is $\mathrm{MB}$ ) then (Tingkat_Kreativitas is SK)

5. If (Kefasihan is SFS) and (Fleksibilitas is FL) and (Kebaruan is $\mathrm{MK}$ ) then (Tingkat_Kreativitas is KR)

6. If (Kefasihan is SFS) and (Fleksibilitas is $\mathrm{FL}$ ) and (Kebaruan is ML) then (Tingkat_Kreativitas is CK)

7. If (Kefasihan is SFS) and (Fleksibilitas is KFL) and (Kebaruan is MB) then (Tingkat_Kreativitas is KR)

8. If (Kefasihan is SFS) and (Fleksibilitas is $\mathrm{KFL}$ ) and (Kebaruan is $\mathrm{MK}$ ) then (Tingkat_Kreativitas is CK)

9. If (Kefasihan is SFS) and (Fleksibilitas is KFL) and (Kebaruan is ML) then (Tingkat_Kreativitas is KK)

10. If (Kefasihan is FS) and (Fleksibilitas is $\mathrm{SFL}$ ) and (Kebaruan is $\mathrm{MB}$ ) then (Tingkat_Kreativitas is SK)

11. If (Kefasihan is FS) and (Fleksibilitas is SFL) and (Kebaruan is MK) then (Tingkat_Kreativitas is KR)

12. If (Kefasihan is FS) and (Fleksibilitas is SFL) and (Kebaruan is ML) then (Tingkat_Kreativitas is CK)

13. If (Kefasihan is FS) and (Fleksibilitas is FL) and (Kebaruan is $\mathrm{MB}$ ) then (Tingkat_Kreativitas is KR)

14. If (Kefasihan is FS) and (Fleksibilitas is FL) and (Kebaruan is MK) then (Tingkat_Kreativitas is CK)

15. If (Kefasihan is FS) and (Fleksibilitas is FL) and (Kebaruan is ML) then (Tingkat_Kreativitas is KK)

16. If (Kefasihan is FS) and (Fleksibilitas is KFL) and (Kebaruan is MB) then (Tingkat_Kreativitas is KR)

17. If (Kefasihan is FS) and (Fleksibilitas is KFL) and (Kebaruan is MK) then (Tingkat_Kreativitas is CK) 
18. If (Kefasihan is FS) and (Fleksibilitas is KFL) and (Kebaruan is ML) then (Tingkat_Kreativitas is KK)

19. If (Kefasihan is KFS) and (Fleksibilitas is $\mathrm{SFL}$ ) and (Kebaruan is MB) then (Tingkat_Kreativitas is KR)

20. If (Kefasihan is KFS) and (Fleksibilitas is SFL) and (Kebaruan is MK) then (Tingkat_Kreativitas is CK)

21. If (Kefasihan is KFS) and (Fleksibilitas is SFL) and (Kebaruan is ML) then (Tingkat Kreativitas is KK)

22. If (Kefasihan is KFS) and (Fleksibilitas is FL) and (Kebaruan is MB) then (Tingkat_Kreativitas is CK)

23. If (Kefasihan is KFS) and (Fleksibilitas is FL) and (Kebaruan is $\mathrm{MK}$ ) then (Tingkat_Kreativitas is CK)

24. If (Kefasihan is KFS) and (Fleksibilitas is FL) and (Kebaruan is ML) then (Tingkat_Kreativitas is KK)

25. If (Kefasihan is KFS) and (Fleksibilitas is KFL) and (Kebaruan is MB) then (Tingkat_Kreativitas is CK)

26. If (Kefasihan is KFS) and (Fleksibilitas is KFL) and (Kebaruan is MK) then (Tingkat_Kreativitas is CK)

27. If (Kefasihan is KFS) and (Fleksibilitas is KFL) and (Kebaruan is MB) then (Tingkat_Kreativitas is KK)

Bentuk sebuah inferensi sistem fuzzy menggunakan himpunan serta aturan fuzzy yang telah ditetapkan. Evaluasi sistem yang dibangun:

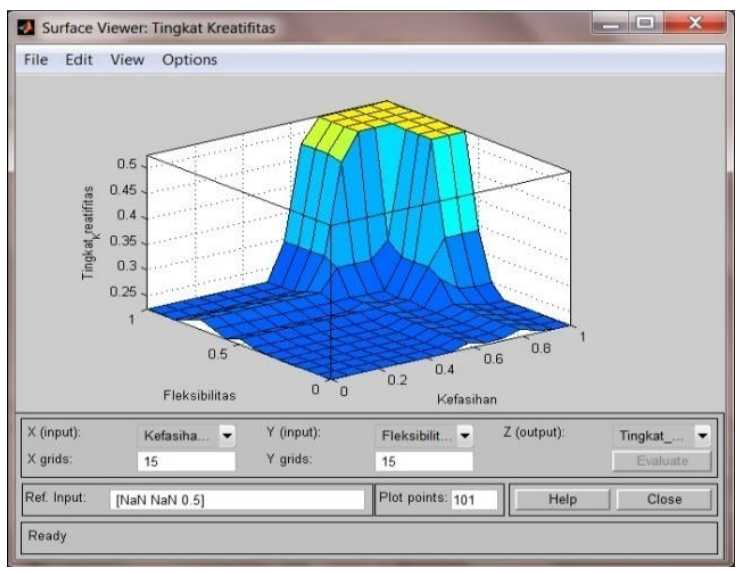

Gambar 8. Fuzzy Surface Viewer
Setelah didapati perhitungan dengan menggunakan Fuzzy Inference System (Mamdani) dengan Matlab, maka didapat hasil sebagai berikut :

\section{Tabel 8. Hasil Perhitungan Tingkat} Kreativitas Siswa

\begin{tabular}{cc}
\hline Siswa X & Tingkat Kreativitas \\
\hline S-1 & Sangat Kreatif \\
S-2 & Kreatif \\
S-3 & Cukup Kreatif \\
S-4 & Cukup Kreatif \\
S-5 & Kurang Kreatif \\
\hline
\end{tabular}

\section{SIMPULAN}

Penentuan Tingkat Kreativitas Siswa Dengan Metode Fuzzy Mamdani, diperoleh kesimpulan sebagai berikut :

1. Proses penentuan tingkat kreativitas siswa dengan metode fuzzy mamdani adalah dengan langkah-langkah: (1) analisis data siswa digolongkan dalam kategori tingkatan kreativitas; (2) mentransformasikan data ke dalam sebuah nilai ukur yaitu: kefasihan $=$ 0.27 , fleksibilitas $=0.33$, Kebaharuan $=$ 0.40 ; (3) menjumlahkan nilai pada semua kategori pada masing-masing siswa; (4) spesifikasi masalah dan definisikan linguistic variables; (5) Buat aturan fuzzy; (6) Buat aturan fuzzy ; (7) Bentuk sebuah inferensi sistem fuzzy menggunakan himpunan serta aturan fuzzy yang telah ditetapkan;

Evaluasi sistem yang dibangun; (9) mendapat akan rentang tingkatan kreativitas; (10) menyimpulkan siswa ke dalam masing-masing tingkatan kreativitas.

2. Hasil penentuan tingkat kreativitas siswa dengan metode fuzzy mamdani adalah rentangan tingkatan kreativitas siswa yaitu: (1) sangat kreatif rentang $0,8-1 ;$ (2) kreatif rentang $0,65-0,7$; (3) cukup kreatif rentang 0,4-0,5; kurang kreatif rentang $0-0,3$. 


\section{DAFTAR PUSTAKA}

[1] A. Y. Wang. "Contexts of Creative Thinking: A Comparison on Creative Performance of Student Teachers in Taiwan and The United States". Journal of International and CrossCulltural Studies, vol. 2, no. 5, pp: 391-396, 2012.

[2] H. Awang dan I. Ramly. "Creative Thinking Skill Approach Through Problem-Based Learning: Pedagogy and Practice in The Engineering Classroom". International Journal of Social, Education, Economics and Management Engineering, vol. 4, no. 4, pp: 26-31, 2008.

[3] N. Eragamreddy. "Teaching Creative Thinking Skills". International Journal of English Language \& Translation Studies, vol. 2, no. 1, pp: 124-145, 2013.

[4] T. Y. E. Siswono. "Level Of Student's Creative Thinking In Classrom Mathematics". Academic Journal. Education Research and Review, vol. 7, no. 6, pp: 548-553, 2007.

[5] G. Bojadziev dan M. Bojadzie. Fuzzy logic for Business, Finance, and Management $2^{\text {nd }}$ Edition. Singapore: World Scientific, 2007 